\title{
Pemetrexed for Ovarian Cancer: A Systematic Review of the Published Literature and a Consecutive Series of Patients Treated in a Nonclinical Trial Setting
}

\author{
Heidi Egloff ${ }^{a}$ Aminah Jatoi ${ }^{b}$ \\ Departments of ${ }^{\mathrm{a}}$ Medicine and ${ }^{\mathrm{b}}$ Oncology, Mayo Clinic, Rochester, Minn., USA
}

\section{Key Words}

Pemetrexed · Ovarian cancer · Antineoplastic activity

\begin{abstract}
Objective: To gain a better understanding of the role of pemetrexed in ovarian cancer patients, we conducted a systematic review of the published literature and evaluated a consecutive, single-institution series of non-study pemetrexed-treated patients. Methods/Results: Thirteen published articles met this study's eligibility criteria, providing a total of 376 unique and evaluable ovarian cancer patients. This systematic review demonstrated tumor response rates with pemetrexed-based chemotherapy from 9 to $84 \%$; the agent appeared to be well tolerated. Similarly, 13 consecutive patients with ovarian, fallopian tube, or primary peritoneal cancer were treated with pemetrexed at the Mayo Clinic, Rochester, Minn., USA, from 2004 through 2013. The median number of previous chemotherapy regimens was 4; most patients received single-agent pemetrexed $(n=9)$. Patients received a median of 2 cycles of pemetrexed-based chemotherapy; 1 patient received 10 cycles (7 months' worth) with treatment ongoing at the time of this report. The median survival from the start of pemetrexed was 4.8 months (95\% confidence interval 1.2, 15 months). Two patients manifested a $50 \%$ drop in Ca-125 levels. Again, pemetrexed was relatively well tolerated. Conclusion: Pemetrexed has antineoplastic activity in patients with ovarian cancer - even among those who have been heavily pretreated - and therefore merits further study.
\end{abstract}




\section{Introduction}

Pemetrexed is an antifolate chemotherapy agent that has been tested in several large phase III studies. Similar in structure to folic acid, pemetrexed blocks the formation of precursor purine and pyrimidine nucleotides, thus inhibiting DNA formation and thus interfering with malignant cell replication [1]. This chemotherapy agent has redefined the standard of care for certain groups of cancer patients, such as those with adenocarcinoma of the lung and mesothelioma [2,3]. Subsequent studies in patients with ovarian cancer have been much smaller in scale but have shown preliminary evidence of antineoplastic activity. To our knowledge, however, large phase III studies with pemetrexed in ovarian cancer patients are neither ongoing nor planned.

The current study was undertaken to address gaps in the published literature and to report a broad-based summary of the current role of pemetrexed in ovarian cancer patients. With respect to gaps, clinical data on pemetrexed in ovarian cancer patients have been confined to prospectively conducted clinical trials, but clinical outcomes tend to be more favorable in patients who are treated within the context of a prospectively conducted clinical trial. Illustrating this point, Unger et al. [4] have recently examined survival in cancer patients who participated in prospective clinical trials and compared outcomes between patients who did and did not participate in a clinical trial. One-year survival was better among cancer clinical trial participants, possibly reflecting the preferential selection of trial candidates. Clinical trial eligibility criteria typically select for healthier, fitter patients who are destined to live longer. Thus, in a single arm study or a small randomized trial, improved outcomes may not necessarily be attributable to the intervention but rather to the selection bias conferred by trial eligibility criteria. Exploring whether pemetrexed also confers favorable clinical outcomes and antineoplastic effects outside a clinical trial would be of value. Secondly, although an earlier study from Miller et al. [5] provided a systematic review of the published literature on pemetrexed in patients with gynecological malignancies, this review did not focus specifically on ovarian cancer patients and did not include phase I studies conducted in patients with a broad range of cancer types that also included ovarian cancer patients. Re-reviewing the published literature with the goal of capturing all clinical response data relevant to ovarian cancer patients would provide a broad-based perspective on the role of pemetrexed in treating ovarian cancer.

In this context, the current study was undertaken with a twofold purpose. First, we sought to provide a comprehensive, systematic review of the published literature to include all reported ovarian cancer patients treated with pemetrexed in a clinical trial setting. Second, we sought to report clinical outcomes within a consecutive series of ovarian cancer patients who were treated with pemetrexed outside a clinical trial setting. This study was intended to provide a comprehensive appraisal of the role of pemetrexed in patients with ovarian cancer.

\section{Methods}

Overview

As noted, this was a two-part study. For the human subjects' portion, the Mayo Clinic Institutional Review Board provided approval. Because pemetrexed received Food and Drug Administration (FDA) approval for clinical use in 2004, the study team focused on all patients who had a diagnosis of ovarian cancer, fallopian tube cancer, or primary peritoneal cancer and who had received treatment with pemetrexed within this interval. In this report, 
the term ovarian cancer is used to include patients with the other two cancer types noted above.

\section{Review of Published Papers on Pemetrexed and Ovarian Cancer}

The search terms, 'ovarian and pemetrexed', 'fallopian tube and pemetrexed', and 'peritoneal and pemetrexed' were used to acquire all germane, prospectively conducted clinical trials on PubMed ${ }^{\circledR}$. This search engine was chosen because it includes articles from other relevant search engines such as Medline,because it pulls citations and abstracts from the multidisciplinary fields of medicine and general healthcare (PubMed Help 2005), and because this approach has precedent [5]. The abstracts of all full manuscripts were screened initially to assess whether the manuscript appeared to be in alignment with this study's goals, as stated earlier. If the abstract was in alignment, the full manuscript was retrieved, printed, read, and summarized. The study team continued to search for other relevant articles by examining references within other articles and by using other approaches, such as discussions with colleagues.

\section{Acquisition and Review of Medical Records}

The Mayo Clinic Tumor Registry provided a list of all ovarian cancer patients who were treated at the Mayo Clinic in Rochester, Minn., USA, during the period noted above. Medical records were reviewed to identify all who had received pemetrexed. Thereafter, a member of the study team (H.E.) undertook an in depth review of each medical record to gather specific information such as patient date of birth, date of death or last follow-up, tumor histology, prior chemotherapy and subsequent chemotherapy, whether single agent pemetrexed or a pemetrexed-based regimen was administered, number of pemetrexedbased chemotherapy cycles prescribed, reason for stopping chemotherapy, and adverse events from all patients who received pemetrexed. Another member of the study team (A.J.) spot-checked abstracted information to ensure accuracy. Information on the date of death or date of the last follow-up was also retrieved. The latter was obtained from the medical record itself and, via the Mayo Clinic Tumor Registry, from the Social Security Death Index, when available.

\section{Analyses and Data Presentation}

Findings from the systematic review and patient series are presented with descriptive statistics such as medians, ranges, and percentages. Systematic review findings are provided in table format. Reporting of vital status with censoring was undertaken, as appropriate. A Kaplan Meier curve was constructed to show survival for the whole patient case series.

\section{Results}

\section{Systematic Review}

A total of 13 articles met this study's eligibility criteria and were reviewed and included. These articles enable us to report data from a total of 376 unique and evaluable ovarian cancer patients. Response rates with pemetrexed-based chemotherapy ranged from 9 to 84\% (table 1).

Demographics within the Consecutive Case Series

Thirteen patients with ovarian cancer were treated at the Mayo Clinic from 2004 through 2013. Most patients received single-agent pemetrexed $(n=9)$. Demographics of the 
patient population are depicted in table 2 . The median number of previous chemotherapy regimens was 4; 1 patient received as many as 9 previous chemotherapy regimens.

Pemetrexed Treatment and Clinical Outcomes within the Consecutive Case Series

Patients received a median of 2 cycles of pemetrexed-based chemotherapy with 1 patient having received 10 cycles, or 7 months' worth (table 3). The median survival from starting pemetrexed was 4.8 months (95\% confidence interval 1.2, 15 months) (fig. 1). Of note, 2 patients manifested a $50 \%$ drop in Ca-125 levels after starting pemetrexed-based chemotherapy. At the time of this report, the patient who received 10 chemotherapy cycles continues with this pemetrexed-based chemotherapy regimen as seventh-line treatment.

Six patients were hospitalized after starting pemetrexed, and adverse events included neutropenia/fevers $(n=1)$, infection $(n=2)$, dehydration $(n=2)$, bowel obstruction $(n=1)$, and others $(\mathrm{n}=2)$. The most common reason for stopping pemetrexed was cancer progression $(n=8)$, but adverse events were the reason in 3 patients.

\section{Discussion}

The purpose of this study was to report a broad-based experience of the antineoplastic activity of pemetrexed in patients with ovarian cancer. The systematic review reported here included all reported ovarian cancer study patients who, to our knowledge, had received pemetrexed in a clinical trial setting. This systematic review found notable tumor response rates - as high as $84 \%$ in one study - to indicate further that pemetrexed has valid antineoplastic activity in patients with ovarian cancer. Secondly, based on the consecutive series reported here, 2 patients manifested a notable drop in the Ca-125 level. In fact, at the time of this report, 1 patient who received a pemetrexed-based chemotherapy regimen as seventhline therapy manifested a 50\% decline in her Ca-125 level, has been on this treatment for 7 months, and currently continues to receive it. This patient is particularly remarkable because her cancer is responding to a pemetrexed-based seventh line chemotherapy intervention. Thus, it appears that pemetrexed is another agent of value in the treatment of patients with ovarian cancer, and it appears that this agent should perhaps be a candidate for future clinical trials in ovarian cancer.

In concert with the findings presented in this report, other antifolate agents have demonstrated preliminary antineoplastic activity in the treatment of ovarian cancer. Farletuzumab, a monoclonal antibody that targets the folate receptor, failed to meet its primary endpoint in a recent phase III trial, but exploratory post hoc analyses suggest trends in improvement in progression-free survival in patient subgroups [6]. Potentially, farletuzumab may merit further testing in subgroups of ovarian cancer patients. Additionally, in a randomized phase II trial, vintafolide, another antifolate conjugated with the chemotherapy agent vinblastine, demonstrated an improvement in progression-free survival from 2.7 to 5 months, although again phase III results have shown less promise [7]. Nonetheless, the foregoing underscore the fact that antifolates have activity in the treatment of ovarian cancer and suggest that pemetrexed, too, might merit further testing.

The current report sought to be as comprehensive as possible with the goal of providing a firm conclusion on pemetrexed's antineoplastic effects in ovarian cancer patients. However, some words of caution are in order. First, our approach of including all ovarian cancer patients who had participated in clinical trials in our systematic review - even in phase I studies - might introduce a slight bias that overstates pemetrexed's antineoplastic activity. In eliciting phase I studies that are not specific to patients of a certain cancer type, 
the reporting of positive antineoplastic responses selects for the declaration of the responder's cancer type. Other ovarian cancer patients who did not respond to pemetrexed might not be mentioned by cancer type within the trial report, thereby biasing results in favor of ovarian cancer responders. Because patients with ovarian cancer represent only a small subset of patients who participate in clinical trials, this bias is likely negligible but nonetheless merits mention. Second, previous studies show that tumor response rates tend to be overreported in phase II trials compared to larger phase III trials for a variety of reasons, some of which remain inexplicable and some of which may hinge on the testing of dual agents [8]. This study attempted to address the salient issue of selection bias within clinical trials but by no means obviates the value of a phase III study to report accurate and precise tumor response rates, to characterize comparative adverse event data in a more comprehensive manner, and to provide definitive data on survival. We conclude that pemetrexed has antineoplastic activity in ovarian cancer patients and that this agent merits further study.

\section{Acknowledgment}

This work was supported by 5K24CA131099.

\section{References}

1 Chen VJ, Bewley JR, Andis SL, et al: Cellular pharmacology of MTA: a correlation of MTA-induced cellular toxicity and in vitro enzyme inhibition with its effects on intracellular folate and nucleoside triphosphate pools in CCRF-CEM cells. Semin Oncol 1999;26:48-54.

$\checkmark 2$ Vogelzang NJ, Rusthoven JJ, Symanowski J, et al: Phase III study of pemetrexed in combination with cisplatin versus cisplatin alone in patients with malignant pleural mesothelioma. J Clin Oncol 2003;21:2636-2644.

-3 Paz-Ares LG, de Marinis F, Dediu M, et al: PARAMOUNT: final overall survival results of the phase III study of maintenance pemetrexed versus placebo immediately after induction treatment with pemetrexed plus cisplatin for advanced nonsquamous non-small-cell lung cancer. J Clin Oncol 2013;31:2895-3902.

4 Unger JM, Barlow WE, Martin DP, et al: Comparison of survival outcomes among cancer patients treated in and out of clinical trials. J Natl Cancer Inst 2014;106:dju002.

5 Miller DS, Tai DF, Obasaju C, Vergote I: Safety and efficacy of pemetrexed in gynecological cancers: a systematic literature review. Modern Chemotherapy 2013;2:19-32.

6 Armstrong DK, White AJ, Weil SC, Phillips M, Coleman RL: Farletuzumab (a monoclonal antibody against folate receptor alpha) in relapsed platinum sensitive ovarian cancer. Gynecol Oncol 2013;129:452-458.

7 Graybill WS, Coleman RL: Vintafolide: a novel targeted agent for epithelial ovarian cancer. Future Oncol 2014;10:541-548.

-8 Sznol M: Reporting disease control rates or clinical benefit rates in early clinical trials of anticancer agents: useful endpoint or hype? Curr Opin Investig Drugs 2010;11:1340-1341.

-9 Hagemann AR, Novetsky AP, Zighelboim I, et al: Phase II study of bevacizumab and pemetrexed for recurrent or persistent epithelial ovarian, fallopian tube or primary peritoneal cancer. Gynecologic Oncology 2013;131:535-540.

10 Chambers SK, Chow S, Janicek MF, et al: Phase 1 trial of intraperitoneal pemetrexed, cisplatin, and paclitaxel in optimally debulked ovarian cancer. Clin Cancer Res 2012;18:2668-2678.

11 Sehouli J, Alvarez AM, Manouchehrpour S, et al: A phase II trial of pemetrexed in combination with carboplatin in patients with recurrent ovarian or primary peritoneal cancer. Gynecol Oncol 2012;124:205209.

12 Richards DA, Loesch D, Vukelja SJ, et al: Phase I study of pemetrexed and pegylated liposomal doxorubicin in patients with refractory breast, ovarian, primary peritoneal, or fallopian tube cancer. Invest New Drugs 2011;29:963-970.

13 Sehouli J, Camara 0, Mahner S, et al: A phase I trial of pemetrexed plus carboplatin in recurrent ovarian cancer. Cancer Chemotherapy Pharmacol 2010;66:861-868.

14 Miller DS, Blessing JA, Krasner CN, et al: Phase II evaluation of pemetrexed in the treatment of recurrent or persistent platinum resistant ovarian or primary peritoneal carcinoma: a study of the Gynecological Oncology Group 2009;27:2686-2691. 
Egloff and Jatoi: Pemetrexed for Ovarian Cancer: A Systematic Review of the Published

15 Vergote I, Calvert H, Kania M, et al: A randomized, double-blind, phase II study of two doses of pemetrexed in the treatment of platinum-resistant, epithelial ovarian or primary peritoneal cancer. Eur J Cancer 2009;45:1415-1423.

16 Gasent Blesa JM, Alberolla Candel V, Provencio Pulla M, et al: Management of platinum-resistant ovarian cancer with the combination of pemetrexed and gemcitabine. Clin Transl Oncol 2009;11:35-40.

17 Hensley ML, Larkin J, Fury M, et al: A phase I trial of pemetrexed plus gemcitabine given biweekly with Bvitamin support in solid tumor malignancies or advanced epithelial ovarian cancer. Clin Cancer Res 2008;14:6310-6316.

18 Matulonis UA, Horowitz NS, Campos SM, et al: Phase II study of carboplatin and pemetrexed for the treatment of platinum-sensitive recurrent ovarian cancer. J Clin Oncol 2008;26:5761-5766.

19 Kalykaki A, Vamvakas L, Agelaki S, et al: A dose escalation study of gemcitabine plus pemetrexed administered biweekly in patients with solid tumors. Oncology 2006;71:197-203.

20 Misset JL, Gamelin E, Campone M, et al: Phase I and pharmacokinetic study of the multitargeted antifolate pemetrexed in combination with oxaliplatin in patients with advanced solid tumors. Ann Oncol 2004;15:1123-1129.

21 Adjei AA, Erlichman C, Sloan JA, et al: Phase I and pharmacologic study of sequences of gemcitabine and the multitargeted antifolate in patients with advanced solid tumors. J Clin Oncol 2000;18:1748-1757. 


\section{Case Reports in Oncology}

\begin{tabular}{l|l}
\hline Case Rep Oncol 2014;7:541-549 \\
\hline DOI: $10.1159 / 000365885$ & $\begin{array}{l}\text { (c) 2014 S. Karger AG, Basel } \\
\text { www.karger.com/cro }\end{array}$ \\
\hline
\end{tabular}

Egloff and Jatoi: Pemetrexed for Ovarian Cancer: A Systematic Review of the Published Literature and a Consecutive Series of Patients Treated in a Nonclinical Trial Setting

Table 1. Summary of the systematic review

\begin{tabular}{|c|c|c|c|c|c|}
\hline Study & $\begin{array}{l}\text { Number of } \\
\text { ovarian cancer } \\
\text { patients* }\end{array}$ & Study design & $\begin{array}{l}\operatorname{Drug}(\mathrm{s}) \\
\text { tested** }\end{array}$ & Clinical efficacy outcome data & Comments \\
\hline $\begin{array}{l}\text { Hageman } \\
\text { et al. [9] }\end{array}$ & 34 & $\begin{array}{l}\text { third-line or earlier phase II } \\
\text { trial }\end{array}$ & $\begin{array}{l}\text { pemetrexed }+ \\
\text { bevacizumab }\end{array}$ & $\begin{array}{l}\text { 6-month progression-free } \\
\text { survival: } 56 \% \text {; response rate } \\
41 \%\end{array}$ & $\begin{array}{l}2 \text { patients developed } \\
\text { therapy-related } \\
\text { myeloid neoplasms }\end{array}$ \\
\hline $\begin{array}{l}\text { Chambers } \\
\text { et al. [10] }\end{array}$ & 15 & $\begin{array}{l}\text { phase I trial of optimally } \\
\text { debulked patients who might } \\
\text { have received prior } \\
\text { carboplatin/paclitaxel }\end{array}$ & $\begin{array}{l}\text { intraperitoneal } \\
\text { pemetrexed + } \\
\text { cisplatin }+ \\
\text { paclitaxel }\end{array}$ & $\begin{array}{l}\text { response rate among } 13 \text { Ca- } \\
125 \text { evaluable patients: } \\
100 \% \text {; } 18 \text {-month } \\
\text { progression-free survival: } \\
79 \%\end{array}$ & $\begin{array}{l}\text { adjuvant intraperito- } \\
\text { neal trial in high-risk } \\
\text { patients }\end{array}$ \\
\hline $\begin{array}{l}\text { Sehouli } \\
\text { et al. [11] }\end{array}$ & 66 & $\begin{array}{l}\text { third-line or earlier phase II } \\
\text { trial }\end{array}$ & $\begin{array}{l}\text { pemetrexed + } \\
\text { carboplatin }\end{array}$ & $\begin{array}{l}61 \text { evaluable patients, } \\
\text { response rate: } 33 \% \text {; median } \\
\text { progression-free survival: } 9.4 \\
\text { months }\end{array}$ & none \\
\hline $\begin{array}{l}\text { Richards } \\
\text { et al. [12] }\end{array}$ & 19 & $\begin{array}{l}\text { fourth-line or earlier phase I } \\
\text { study }\end{array}$ & $\begin{array}{l}\text { pemetrexed + } \\
\text { liposomal } \\
\text { doxorubicin }\end{array}$ & $\begin{array}{l}\text { response rate of } 36 \% \text { in } 14 \\
\text { evaluable patients; stable } \\
\text { disease in } 9\end{array}$ & well tolerated \\
\hline $\begin{array}{l}\text { Sehouli } \\
\text { et al. [13] }\end{array}$ & 20 & $\begin{array}{l}\text { platinum-sensitive, recurrent } \\
\text { disease }\end{array}$ & $\begin{array}{l}\text { pemetrexed + } \\
\text { carboplatin }\end{array}$ & $\begin{array}{l}\text { response rate in } 19 \text { evaluable } \\
\text { patients: } 84 \%\end{array}$ & well tolerated \\
\hline $\begin{array}{l}\text { Miller et } \\
\text { al. [14] }\end{array}$ & 51 & $\begin{array}{l}\text { phase II trial in platinum- } \\
\text { resistant patients who had } \\
\text { received no more than } 1 \text { prior } \\
\text { chemotherapy }\end{array}$ & pemetrexed & $\begin{array}{l}\text { response rate: } 20 \% \text {; median } \\
\text { progression-free survival: } 2.9 \\
\text { months }\end{array}$ & $\begin{array}{l}\text { United States Cancer } \\
\text { Cooperative Group } \\
\text { trial }\end{array}$ \\
\hline $\begin{array}{l}\text { Vergote } \\
\text { et al. [15] }\end{array}$ & 102 & $\begin{array}{l}\text { randomized phase II trial with } \\
\text { different pemetrexed doses in } \\
\text { patients with no more than } 2 \\
\text { prior chemotherapy regimens }\end{array}$ & pemetrexed & $\begin{array}{l}\text { response rate: } 9-10 \% ; \\
\text { median progression-free } \\
\text { survival: } 2.8 \text { months }\end{array}$ & multicenter trial \\
\hline $\begin{array}{l}\text { Gasent } \\
\text { Blesa et } \\
\text { al. } \\
{[16]} \\
\end{array}$ & 10 & $\begin{array}{l}\text { compassionate use study for } \\
\text { platinum-resistant patients } \\
\text { with any number of prior } \\
\text { chemotherapy regimens }\end{array}$ & $\begin{array}{l}\text { pemetrexed + } \\
\text { gemcitabine }\end{array}$ & response rate: $30 \%$ & $\begin{array}{l}\text { compassionate use } \\
\text { study }\end{array}$ \\
\hline $\begin{array}{l}\text { Hensley et } \\
\text { al. [17] }\end{array}$ & 24 & $\begin{array}{l}\text { phase I study in patients with } \\
\text { different cancer types and an } \\
\text { unlimited number of prior } \\
\text { chemotherapy regimens }\end{array}$ & $\begin{array}{l}\text { pemetrexed + } \\
\text { gemcitabine }\end{array}$ & $\begin{array}{l}\text { among } 21 \text { evaluable patients, } \\
\text { response rate: } 28 \%\end{array}$ & well tolerated \\
\hline $\begin{array}{l}\text { Matulonis } \\
\text { et al. [18] }\end{array}$ & 44 & $\begin{array}{l}\text { phase II study on platinum- } \\
\text { sensitive patients who had } \\
\text { received no more than } 2 \text { prior } \\
\text { regimens for recurrent cancer }\end{array}$ & $\begin{array}{l}\text { pemetrexed + } \\
\text { carboplatin }\end{array}$ & response rate: $51 \%$ & none \\
\hline $\begin{array}{l}\text { Kalykaki } \\
\text { et al. [19] }\end{array}$ & unknown & phase I trial & $\begin{array}{l}\text { pemetrexed + } \\
\text { gemcitabine }\end{array}$ & $\begin{array}{l}1 \text { response in an ovarian } \\
\text { cancer patient }\end{array}$ & none \\
\hline $\begin{array}{l}\text { Misset et } \\
\text { al. [20] }\end{array}$ & 3 & $\begin{array}{l}\text { phase I trial in patients with up } \\
\text { to } 2 \text { prior chemotherapy } \\
\text { regimens }\end{array}$ & $\begin{array}{l}\text { pemetrexed + } \\
\text { oxaliplatin }\end{array}$ & $\begin{array}{l}\text { stable disease observed in an } \\
\text { unspecified number of } \\
\text { ovarian cancer patients }\end{array}$ & none \\
\hline $\begin{array}{l}\text { Adjei et } \\
\text { al. } \\
{[21]}\end{array}$ & 3 & & $\begin{array}{l}\text { pemetrexed + } \\
\text { gemcitabine }\end{array}$ & $\begin{array}{l}2 \text { responses in ovarian cancer } \\
\text { patients }\end{array}$ & none \\
\hline
\end{tabular}

* Ovarian cancer includes ovarian, fallopian tube, and primary peritoneal carcinoma.

** Agents were administered intravenously, unless otherwise stated. 
Egloff and Jatoi: Pemetrexed for Ovarian Cancer: A Systematic Review of the Published

Table 2. Baseline demographics of 13 ovarian cancer patients

Median age at diagnosis years (range), years

Tumor histology

Papillary serous

Other

Chemotherapy agent prescribed with pemetrexed

None

Carboplatin

Bevacizumab

Median number of prior chemotherapy regimens (range)
$61(37,92)$

$11(85)$

$1(8)$

$4(1,9)$

Numbers in parentheses represent percentages of patients, unless otherwise specified.

Table 3. Pemetrexed outcomes $(n=13)$

\begin{tabular}{lc}
\hline Characteristic & $\begin{array}{c}\text { Number of } \\
\text { patients }\end{array}$ \\
\hline $\begin{array}{l}\text { Median number of pemetrexed doses (range) } \\
\text { Reasons for stopping pemetrexed }\end{array}$ & $2(1,10)$ \\
$\quad$ Cancer progression & $8(62)$ \\
Toxicity & $3(23)$ \\
Other & $2(15)$ \\
Hospitalized after starting pemetrexed? & \\
Yes & $6(46)$ \\
No & $6(46)$ \\
Unknown & $1(8)$ \\
Adverse events with pemetrexed & $1(8)$ \\
$\quad$ Neutropenia/fevers & $2(16)$ \\
Infection & $2(16)$ \\
Dehydration & $1(8)$ \\
Bowel obstruction & $2(16)$ \\
Other & \\
Ca-125 dropped by 50\% on pemetrexed? & $2(15)$ \\
Yes & $10(77)$ \\
No & $1(8)$ \\
Unknown & $0(0,6)$ \\
Median number of chemotherapy regimens after & \\
stopping pemetrexed (range) & \\
\hline
\end{tabular}

Numbers in parentheses represent percentages of patients, unless otherwise specified.

Percentages do not always sum to 100 because of rounding or partial inclusion of the cohort within a category. 
Egloff and Jatoi: Pemetrexed for Ovarian Cancer: A Systematic Review of the Published Literature and a Consecutive Series of Patients Treated in a Nonclinical Trial Setting

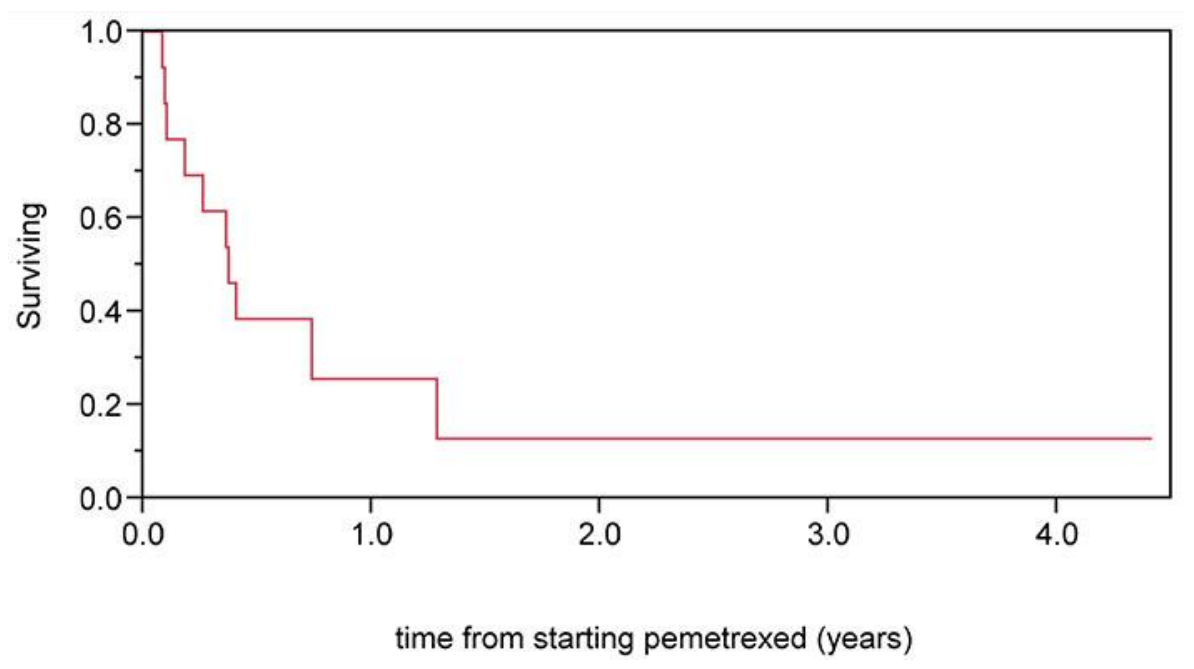

Fig. 1. The median survival from starting pemetrexed was 4.8 months (95\% confidence interval $1.2,15$ months). 